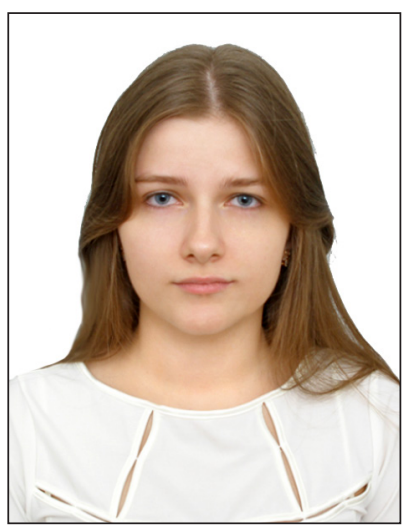

\title{
Попович Наталія Василівна,
} аспірант НДІ державного будівництва та місчевого самоврядування НАПрН України, Україна, м. Харків

e-mail:n1popovych@gmail.com

ORCID 0000-0003-0060-347X

\section{doi: 10.21564/2414-990x.135.82094 \\ YAK 340.134(4)}

\section{КОНСТИТУЦІЙНІ ЗАКОНИ В КРАЇНАХ ВИШЕГРААСЬКОӤ ГРУПИ}

Досліджується місце конституційних законів у системі конституційного законодавства об'єднання чотирьох центральноєвропейських краӥн: Республіки Польща, Угорщини, Республіки Словаччина та Республіки Чехії. 3'ясовуються характерні ознаки конституційних законів, у тому числі їх особливої процедури прийняття, зміни і доповнення.

Ключові слова: Конституція; конституційний закон; органічний закон; референдум; Вишеградська група.

Попович Н. В., аспирант НИИ государственного строительства и местного самоуправления НАПрН Украины, Украина, г. Харьков.

e-mail: n1popovych@gmail.com ; ORCID 0000-0003-0060-347X

Конституционные законы в странах Вышеградской группы

Исследуется место конституционных законов в системе конституционного законодательства объединения четьрёх центральноевропейских стран: Республики Польша, Венгрии, Республики Словакия и Чешской Республики. Определяются характерные признаки конституционных законов, в том числе их особой процедуры принятия, изменения и дополнения.

Ключевые слова: конституция; конституционный закон; органический закон; референдум; Вышеградская группа.

Bcmyn. Процеси правової інтеграції, які характерні для сучасної Європи, трансформують їі правові системи. Найбільші зміни спостерігаються у національних системах джерел континентального права, де, як відомо, головне місце займають конституції. Центральним питанням сучасної конституційної дискусії є наявність прогалин у конституції, а також те, хто, яким чином і в якому напрямку буде заповнювати ці прогалини. Необхідність конституційного оновлення в Україні ставить на порядок денний питання поняття конституційного 
закону. У цьому контексті актуальним видається досвід держав Центральної Свропи, зокрема країн Вишеградської групи.

Аналіз літературних даних і постановка завдання дослідження. Поняття конституційного закону досліджувалося у працях таких вітчизняних і зарубіжних авторів, як О. Гайова (Hajova О.), К. Кармазіна (Karmazina К.), В. Качур (Kachur V.), В. Кириченко (Kyrychenko V.), О. Кириченко (Kyrychenko О.), О. Куракін (Kurakin O.), О. Ревер (Rever О.), Н. Пархоменко (Parkhomenko N.), Б. Банашак (Banashak B.), А. Бень-Касал (Ben’-Kasal А.), Ф. Вейре (Vejre F.), C. Вроньковська (Vron'kovs'ka S.), Р. Давид (Davyd R.), Г. Кюппер (Kiupper H.), P. Леже (Lezhe R.), Д. Шпопер (Shpoper D.).

Memою cmammi є дослідження сутності та функціонального призначення конституційних законів країн Вишеградської групи, їх конкретних характеристик і різновидів, особливостей прийняття та місце у системі законодавства.

Виклад основного матеріалу. Сучасна система джерел права Вишеградської групи у ході історичного розвитку формувалася під впливом римського, австрійського (германського) ${ }^{1}$, соціалістичного (радянського) права, сьогодні вона ідентифікується як система континентального права, яка зазнає змін та розвивається під впливом європейських міжнародних правових стандартів i цінностей (права Свропейського Союзу), що формуються насамперед у межах континентального права.

Ідентифікаційною ознакою романо-германського права є наявність конституції - основного закону. У правових системах Угорщини, Республіки Словаччина, Республіки Польща конституція діє як єдиний закон. Терміни «конституція» і «основний закон» зазвичай виступають синонімами, а їх застосування зумовлене політико-правовими традиціями, що склалися в різних країнах. Визначення конституції основним законом означає акцентування на iii основоположності щодо держави та їі конкретних органів. Однаковою мірою таке визначення означає, що конституція є основою, змістовим і формальним стрижнем системи національного (внутрішньодержавного) права, але ніяк не різновидом законів ${ }^{2}$.

Властивості Конституції як нормативно-правового акта найвищої сили засвідчуються терміном «Основний закон», який в Угорщині є офіційною назвою конституції. Деякі угорські юристи наголошують на тому, що застосування історичного терміна «Основний закон» наводить на думку, що Угорщина повернулась до досоціалістичних традицій, коли конституційні питання врегульовувалися звичайними законами ${ }^{3}$ [2, с. 25].

У Чеській Республіці «незмінною основою правопорядку», складовою частиною конституційної системи є прийнята у формі конституційного закону

\footnotetext{
${ }^{1}$ При цьому слід зауважити, що хоча правові системи належать до романо-германського (континентального) типу, проте в ті чи інші періоди розвитку набували особливостей то романського, то германського підтипів.

${ }^{2}$ Саме такий підхід знаходить підтвердження у частині (3) статті Т Конституції Угорщини [1].

${ }^{3}$ До 1949 р. в Угорщині не було писаної конституції, з коротким проміжком 1918 р. (демократичної революції) і 1919 р. (комуністичної революції).
} 
Хартія основних прав та свобод (ст. 3 Конституції Чеської Республіки) [3], яка складається із 44 статей, визначає правовий статус особи та механізм його забезпечення. У цьому разі конституційний закон наділений юридичними якостями конституції як основного закону і має найвищу юридичну силу.

Конституційні закони ${ }^{1}$ у деяких країнах Вишеградської четвірки слугують офіційною назвою нормативно-правових актів. Так, у правовій системі Чеської Республіки конституційними законами визначені акти, якими вносяться зміни та доповнення до Конституції - п. 1 ст. 9 Конституції Чеської Республіки 1992 р. проголошено, що «Конституція може бути доповнена або змінена тільки конституційними законами», за юридичною силою вони також об'єктивно не можуть відрізнятися від самого основного закону.

Зміни до конституції мають форму нормативно-правового акта, який має таку ж саму юридичну силу, як і конституція: поправки до конституції і сама конституція розглядаються як змістове ціле. Після набуття чинності акти про внесення змін до конституції, як правило, стають частиною основного закону, інтегруються з конституційним текстом, інколи існують формально поза рамками цього тексту, виступаючи у ролі доповнення. Цей документ зазвичай має назву закону про внесення змін. Така назва спричиняє ряд непорозумінь у теоpiї конституційного права і стосується співвідношення понять конституції та закону при визначенні юридичної природи актів. У ряді країн для позначення актів про внесення змін до основного закону використовуються інші назви конституційний закон, поправка, зміна до конституції тощо.

Розробка законопроекту щодо внесення змін до конституції може здійснюватися главою держави, парламентом, у деяких країнах - спеціально створеним органом² (конституційні комісії, спеціальний консультативний орган, установчі збори). В окремих країнах ініційовані до парламентського розгляду проекти актів щодо змін основного закону підлягають конституційному контролю. В інших - вимагається, щоб законопроект про внесення змін до конституції було прийнято двічі, з певним інтервалом у часі. Також у світовій практиці має місце порядок затвердження змін до основного закону парламентами двох скликань. За таких умов передбачається кілька голосувань кожним складом парламенту щодо прийняття відповідного акта. У деяких країнах рішення парламенту повинно бути затверджено референдумом.

\footnotetext{
${ }^{1} \mathrm{y}$ теорії і практиці його нерідко використовували як синонім термінів «конституція» $\mathrm{i}$ «основний закон».

2 Для деяких держав є характерним делегування функцій органу установчої влади не спеціально створеним для цього органам, а парламенту країни. Так, наприклад за конституційним законодавством Польщі законодавчу владу в країні здійснюють Сейм і Сенат, які працюють самостійно, окремо один від одного, але у разі необхідності прийняття конституції держави об'єднуються для спільного проведення засідання і в такому разі мають назву «Національні збори». У статті 1 Закону «Про режим підготовки і прийняття Конституції Польської Республіки» визначалося, що «перша польська конституція, попередньо прийнята сеймом і сенатом у складі Національних зборів, затверджується народом шляхом конституційного референдуму». Національні збори 2 квітня 1997 р. прийняли чинну Конституцію Польщі, яка була затверджена рішенням загальнодержавного референдуму 25 травня 1997 р. [4, с. 376].
} 
У Словаччині, Угорщині та Чехії парламент остаточно приймає закон про внесення змін до Конституції. У Польщі на законодавчому рівні передбачено проведення референдуму як однієї із стадій процесу внесення змін до Конституції. Так, на обов'язковий конституційний референдум можуть бути винесені питання зміни положень Конституції, що стосуються засад республіканського ладу, а також прав, свобод та обов'язків особи та громадянина.

Законопроект про внесення змін до Розділів I, II та XII Конституції може бути винесений на затвердження загальнонаціональним референдумом за ініціативою Президента, п’ятої частини членів верхньої або нижньої палати парламенту протягом 45 днів після схвалення законопроекту про внесення змін до Конституції верхньою палатою парламенту Польщі (референдум проводиться упродовж 60 днів після внесення пропозиції щодо його проведення) (п. 1, п. 6 ст. 235). Право призначати загальнонаціональний референдум належить нижній палаті парламенту Польщі (рішення про проведення референдуму приймається більшістю депутатів Сейму, присутніх на його засіданні, за умови, що на засіданні присутні не менше половини складу Сейму); президенту, який призначає референдум за згодою Сенату (рішення про надання згоди на призначення референдуму приймається більшістю сенаторів, присутніх на засіданні, за умови, що на засіданні присутні не менше половини складу Сенату) (п. 2 ст. 125). Результати загальнонаціонального референдуму підлягають виконанню у разі, якщо у них взяло участь більше половини зареєстрованих виборців (п. 3 ст. 125). Дійсність результатів загальнодержавного референдуму визначає Верховний Суд (ч. 4 ст. 125) [5].

У юридичній теорії і практиці окремих країн, крім конституційних законів, що замінюють основний закон, виділяють і інші конституційні закони. Останні не $є$ частиною основного закону і пов'язані з ним лише за змістом. У Чехії та Словаччині конституційними законами офіційно названі нормативно-правові акти, прийняття яких з питань, визначених у конституції, передбачене самою конституцією (ст. 11, ч. 3 ст. 100 Конституції Чеської Республіки, ч. 2 ст. 3 Конституції Республіки Словаччина) [6]. Об’єкти регулювання, здійснюваного такими конституційними законами, є водночас об'єктами власне конституційного регулювання, адже вони позначені в конституції. Можна припустити, що ці акти за силою є нижчими щодо конституції, але вищими щодо так званих звичайних законів ${ }^{1}$. Проте таке припущення не знайшло прямого підтвердження у конституційних текстах.

У деяких правових системах конституційним законом дається згода на обов'язковість міжнародних договорів. Так, з припису ст. 86 Конституції Республіки Словаччина 1992 р. випливає, що суб'єкт законотворчості (Національна Рада) у формі конституційного закону схвалює договір про вступ Республіки Словаччина

\footnotetext{
${ }^{1}$ У Словаччині конституційні закони виступають критерієм конституційності інших нормативно-правових актів. «Конституційний суд приймає рішення про відповідність: а) законів Конституції, конституційним законам і міжнародним договорам...» (ч. 1 ст. 125 Конституції Республіки Словаччина).
} 
до державного союзу з іншими державами, або про вихід із такого союзу, і відповідні акти підлягають наступному затвердженню на референдумі (статті 7, 93).

Рішення референдуму вважається ухваленим, якщо участь у референдумі взяло більше 50 \% зареєстрованих виборців і відповідне рішення було підтримане більшістю тих, хто взяв участь у референдумі. Слід зазначити, що промульгація рішень, схвалених на референдумі, здійснюється парламентом у тому ж порядку, що і промульгація законів (ст. 98). Парламент може змінити або скасувати результати референдуму шляхом прийняття конституційного закону, але не раніше, ніж через 3 роки після набуття рішенням референдуму законної сили. А референдум щодо питання, яке вже було предметом референдуму, може бути проведений не раніше, ніж через 3 роки після проведення референдуму 3 цього питання (ст. 99). У Словаччині розгляд скарг на результати референдумів здійснює Конституційний Суд (п. 3 ст. 129) [6].

Конституційні закони мають складнішу, ніж звичайні, процедуру ухвалення. На практиці порядок їх прийняття парламентом передбачає застосування правила кваліфікованої більшості ${ }^{1}$, про що говориться в конституціях деяких країн. Наприклад, у п. 4 ст. 84 Конституції Республіки Словаччина 1992 р. зазначено, що «для прийняття Конституції, внесення змін до Конституції, прийняття конституційних законів ... необхідна згода не менше трьох п’ятих голосів усіх депутатів»; у п. 4 ст. 39 Конституції Чеської Республіки 1992 р. визначено, що «для прийняття конституційного закону ... потрібна згода трьох п’ятих голосів від загального числа депутатів та три п’ятих голосів усіх присутніх сенаторів». Однак лише у випадках, коли ця вимога пов'язана 3 власне конституційним регулюванням, вона засвідчує найвищу силу таких актів. 3 іншого боку, у низці країн вимога кваліфікованої більшості стосується інших законів, офіційно не визначених як конституційні ${ }^{2}$. Кваліфікованою більшістю голосів (дві третини

\footnotetext{
${ }^{1}$ Майже правилом щодо прийняття конституційних законів є вимога кваліфікованої більшості (зазвичай у дві треті) від загального складу парламенту.

2 Порядок підготовки та прийняття нової Конституції Польщі був визначений у конституційному законі «Про порядок розробки та схвалення Конституції Республіки Польща» від 23.04.1992 р. Як проміжне рішення 17 жовтня 1992 р. було прийнято третю в історії Польщі Малу Конституцію - конституційний закон про взаємовідносини у стосунках між законодавчою і виконавчою владами Республіки Польща, а також про місцеве самоврядування, який замінив Конституцію, номінально датовану 1952 р., водночас залишивши у силі їі окремі розділи і статті. Конституційний процес було завершено в 1997 р. - Конституція була схвалена Національними зборами 02.04.1997 p. (451 голос «за» і 40 голосів «проти»). Як і було передбачено конституційним законом 1992 р., після цього текст Конституції було внесено на референдум, який було проведено 25.05 .1997 р. (56,8 \% голосів «за», 43,2 \% «проти» при явці виборців у 38,9 \%). Постало питання легітимності Конституції, яке вирішив Верховний суд 15.07.1997 р. Наступного дня, 16.07.1997 р., Конституцію підписав Президент Польської Республіки, а набула вона чинності 17.10 .1997 р. [7, с. 42-44]. Необхідно зауважити, що в Польщі термін «конституційний закон» після прийняття Конституції 1997 р. офіційно на законодавчому рівні не застосовується, хоча окремі юристи і політики вживають цей термін у своїх публікаціях і виступах, узагальнено трактуючи поняття конституційного закону як закону, що пов'язаний насамперед змістом із Конституцією країни, із внесенням змін до неї, ухваленням нової Конституції.
} 
від присутніх на засіданні членів Сейму) приймаються, зокрема, закони про ратифікацію угод, які передбачають передачу частини повноважень органів державної влади міжнародним організаціям, закони про внесення змін до Конституції (п. 2 ст. 90, п. 4 ст. 235 Конституції Республіки Польща). У цих випадках вона лише підтверджує значущість відповідних об'єктів правового регулювання. Питання про вищу юридичну силу таких законів, порівняно з іншими «звичайними» законами, як правило, не виникає.

Вимога абсолютної більшості встановлена конституціями ряду держав і щодо прийняття законів, які не мають форми конституційних. Трьома п’ятими від загальної кількості депутатів та сенаторів приймаються рішення про ратифікацію міжнародних угод, якими передбачається передача частини суверенних повноважень держави міжнародній організації (ст. 10-А, Конституції Чеської Республіки); рішення про скорочення строку повноважень Сейму (двома третинами від конституційного складу Сейму (стаття 98 Конституції Республіки Польща)), рішення про висловлення вотуму недовіри уряду (приймається більшістю від конституційного складу Сейму (ст. 158 Конституції Республіки Польща)). А рішення щодо оголошення війни або іншого стану, висунення обвинувачення Президенту у разі порушення ним Конституції або вчинення державної зради, про оголошення загальнодержавного референдуму щодо припинення повноважень Президента та про передачу частини повноважень органів влади Словаччини Європейському Союзу - трьома п'ятими від конституційного складу парламенту (статті 7, 84, 106 Конституції Республіки Словаччина) [8, с. 37-39].

Порядок прийняття конституційних законів і набуття ними чинності характеризується й іншими особливостями. Відмінною від «звичайної», законодавчої $\epsilon$ процедура їх прийняття парламентом ${ }^{1}$. За загальним правилом глава держави не має права вето стосовно конституційних законів, чим підтверджується їх особлива юридична природа та (або) зв’язок із конституцією.

Державно-правовій теорії і практиці ряду країн відоме поняття органічних законів, які на відміну від конституційних законів не змінюють основних конституційних принципів, приймаються для уточнення або доповнення положень конституції за прямим приписом останньої, на основі бланкетних норм (такі норми лише визначають коло питань, що мають бути врегульовані органічними законами) та зазвичай регулюють один із інститутів конституційного права в цілому. За спільних загальних ознак органічні закони в різних країнах називаються по-різному.

По суті, органічні закони встановлюють головні конституційно-правові інститути в цілому або їх основи. Порядок прийняття, зміни і скасування їх дещо відрізняється від звичайного законодавства, хоча за юридичною силою

\footnotetext{
${ }^{1}$ Конституцією Чехії не визначено кількості читань, у ході яких має проводитись обговорення законопроектів, але зазначено, що у першому читанні та в цілому не може бути схвалений проект закону про державний бюджет, проекти змін до Конституції та проекти законів про ратифікацію окремих типів міжнародних договорів [8, с. 34].
} 
вони тотожні. У ряді країн органічні закони приймаються абсолютною більшістю складу парламенту. Такий самий порядок встановлений і в інших державах, хоч у самій конституції назва «органічні закони» не вживається.

Уперше термін «sarkalatos tцrvйnу» для позначення саме різновиду законів (органічних) було вжито в Конституції Угорщини 2011 р., де зазначається, 3 яких конкретних питань ${ }^{1}$ мають бути прийняті відповідні закони і встановлюється спеціальна процедура прийняття. Зокрема, за певних умов для прийняття або для внесення змін до органічних законів тут також потрібна більшість у дві третини голосів від загального складу парламенту. Разом з тим органічні закони не відрізняються за силою від звичайних законів.

В Угорщині до прийняття Конституції 2011 р. органічні закони взагалі не мали особливої назви, відрізнялися від звичайних законів тільки процедурою прийняття. Більшість законів приймаються простою більшістю голосів. Однак значна кількість законів, що врегульовують найважливіші суспільні інститути, процеси та відносини, у деяких випадках вимагають більшості у дві третини голосів як для їх прийняття, так і для внесення поправок. У минулому це часто блокувало прийняття законів, оскільки угорська політична культура, влада та опозиція не могли співпрацювати належним чином, у майбутньому - практично позбавить уряди (за умови, що вони не контролюватимуть/становитимуть переважну більшість депутатських мандатів) можливості здійснення власної політики, політики законодавчих та кадрових змін. Фахівці у сфері конституційного права Угорщини рекомендують скасувати категорію законів, для прийняття i внесення поправок до яких є необхідним кворум, що становить дві третини голосів [2, с. 32; 9, с. 14].

Висновки. У країнах Вишеградської четвірки конституційні закони виступають складовою частиною конституційної системи. Функціональне призначення конституційних законів у цих країнах різне: внесення змін та доповнень до конституції (Чехія); імплементація міжнародних договорів (Словаччина); регулювання окремих питань передбачених конституцією. У Польщі термін «конституційний закон» після прийняття Конституції 1997 р. офіційно на законодавчому рівні не застосовується, хоча окремі юристи і політики вживають цей термін у своїх публікаціях і виступах, узагальнено трактуючи поняття конституційного закону як закону, що пов’язаний насамперед змістом із Конституцією країни, із внесенням змін до неї, ухваленням нової Конституції.

Отже, під конституційними законами розуміють не лише закони, якими вносяться правки чи доповнення до конституції, але й закони, на які посилається конституція або необхідність прийняття яких прямо передбачена чинною конституцією. Ці закони конкретизують окремі положення конституції, приймаються органами законодавчої влади чи на референдумі за спеціальною процедурою.

\footnotetext{
${ }^{1}$ Як правило, у конституціях передбачено прийняття органічних законів з питань статусу вищих органів виконавчої і судової влади, місцевого самоврядування, виборчої системи, громадянства, організації та діяльності політичних партій, режиму надзвичайного стану тощо.
} 


\section{Список літератури:}

1. Magyarország Alaptörvénye (2011. április 25) [Електронний ресурс]. - Режим доступу : http://njt.hu/cgi_bin/njt_doc.cgi?docid=140968.322953.

2. Кюппер Г. Конституція Угорщини 2011 року / Г. Кюппер // Публічне право. - 2011. № 4. - C. 23-36.

3. Ústava České republiky ze dne 16. prosince 1992 [Електронний ресурс]. - Режим доступу : http://www.psp.cz/docs/laws/constitution.html.

4. Максакова Р. М. Основні форми реалізації установчої влади: Україна та зарубіжний досвід [Електронний ресурс] / Р. М. Максакова // Часопис Київського університету права. - 2012. - № 2. - C. 374-378. - Режим доступу: http://nbuv.gov.ua/UJRN/Chkup_2012_2_91.

5. Konstytucja Rzeczypospolitej Polskiej z dnia 2 kwietnia 1997. - [Електронний ресурс]. - Режим доступу : https://www.google.com.ua/url?sa=t\&rct=j\&q=\&esrc $=$ s\&source $=$ web\&cd $=1 \&$ cad $=$ rja\&u act $=8 \&$ ved $=0$ ahUKEwj2srOOiYzQAhUBEiwKHf45C9QQFggZMAA\&url=http\%3A\%2F\%2Fisap. sejm.gov.pl\%2FDownload\%3Fid\%3DWDU19970780483\%26type\%3D3\&usg=AFQjCNFANwvLs5sb3 ODcWXz1ES UuEfo4A\&bvm=bv.137132246,d.bGg ().

6. Ústava Slovenskej Republiky [Електронний ресурс]. - Режим доступу : https://www. prezident.sk/upload-files/20522.pdf.

7. Болдіжар С. О. Особливості технології конституційної реформи в Польській Республіці: уроки для України [Електронний ресурс] / С. О. Болдіжар // Форум права. - 2013. - № 3. C. 41-45. - Режим доступу: http://www.irbis-nbuv.gov.ua/cgi-bin/irbis nbuv/cgiirbis 64.exe?I21 $\mathrm{DBN}=\mathrm{LINK} \& \mathrm{P} 21 \mathrm{DBN}=\mathrm{UJRN} \& \mathrm{Z} 21 \mathrm{ID}=\& \mathrm{~S} 21 \mathrm{REF}=10 \& \mathrm{~S} 21 \mathrm{CNR}=20 \& \mathrm{~S} 21 \mathrm{STN}=1 \& \mathrm{~S} 21 \mathrm{FMT}=\mathrm{ASP}$ meta\&C21COM=S\&2_S21P03=FILA=\&2_S21STR=FP_index.htm_2013_3_9.

8. Ковриженко Д. Правове регулювання законодавчого процесу: досвід країн СС та пропозиції для України [Електронний ресурс] / Д. Ковриженко // Часопис «Парламент». - 2011. № 1. - С. 2-41. - Режим доступу: http://parlament.org.ua/2015/08/15/chasopis-parlament-12011/.

9. Ілов І. Конституційні зміни в Угорщині 2012: основні новації та їх вплив на суспільно-політичний розвиток держави / I. Ілов // Віче: Теоретичний і громадсько-політичний журнал. - 2013. - № 4. - С. 11-15.

\section{References:}

1. Magyarország Alaptörvénye (2011. április 25). Retrieved from: http://njt.hu/cgi_bin/njt_doc. cgi?docid=140968.322953 [In Hungarian].

2. Kiupper, H. (2011). Konstytutsiia Uhorschyny 2011 roku [The Constitution of Hungary on 2011]. Publichne pravo - Public Law, 4, 23-36 [in Ukrainian].

3. Ústava České republiky ze dne 16. prosince 1992 Retrieved from: http://www.psp.cz/docs/laws/ constitution.html [in Czech]

4. Maksakova, R.M. (2012). Osnovni formy realizatsii ustanovchoi vlady: Ukraina ta zarubizhnyj dosvid [The Main Forms of Implementing the Constituent Power : Ukraine and international experience]. Chasopys Kyivs'koho universytetu prava - Scientific Journal Chronicles of KUL, 2, 374378. Retrieved from: http://nbuv.gov.ua/UJRN/Chkup_2012_2_91 [in Ukrainian].

5. Konstytucja Rzeczypospolitej Polskiej (2 kwietnia 1997). Retrieved from: https://www. google.com.ua/url? sa $=$ t\&rct $=j \& q=\&$ esrc $=$ s\&source $=$ web\& $c d=1 \&$ cad $=$ rja\&uact $=8 \&$ ved $=0$ ahUKE wj2srOOiYzQAhUBEiwKHf45C9QQFggZMAA\&url=http\%3A\%2F\%2Fisap.sejm.gov.pl\%2FDow nload\%3Fid\%3DWDU19970780483\%26type\%3D3\&usg=AFQjCNFANwvLs5sb3ODcWXz1ES_ UuEfo4A\&bvm=bv.137132246,d.bGg () [in Polish].

6. Ústava Slovenskej Republiky. Retrieved from: https://www.prezident.sk/upload-files/20522.pdf [in Slovak].

7. Boldizhar, S.O. (2013). Osoblyvosti tekhnolohii konstytutsijnoi reformy v Pol's'kij Respublitsi: uroky dlia Ukrainy [Technology Features Of Constitutional Reform in Republic of Poland]. Forum prava - Forum prava 3, 41-45. Retrieved from: http://www.irbis-nbuv.gov.ua/cgi-bin/irbis_nbuv/ cgiirbis 64.exe?I21DBN=LINK\&P21DBN=UJRN\&Z21ID $=\& S 21 \mathrm{REF}=10 \& S 21 \mathrm{CNR}=20 \& \mathrm{~S} 21 \mathrm{STN}$ $=1 \& S 21 \mathrm{FMT}=\mathrm{ASP} \_$meta $\& \mathrm{C} 21 \mathrm{COM}=\mathrm{S} \& 2 \_\mathrm{S} 21 \mathrm{P} 03=\mathrm{FILA}=\& 2 \_\mathrm{S} 21 \mathrm{STR}=\mathrm{FP}$ index.htm_2013_3_9 [in Ukrainian]. 
8. Kovryzhenko, D. (2011). Pravove rehuliuvannia zakonodavchoho protsesu: dosvid krain YeS ta propozytsii dlia Ukrainy [Legal regulation of the legislative process: The EU Experience and proposals for Ukraine]. Chasopys «Parlament»-Chronicles of Parliament 1, 2-41. Retrieved from: http://parlament.org.ua/2015/08/15/chasopis-parlament-12011/ [in Ukrainian].

9. Ilov, I. (2013). Konstytutsijni zminy v Uhorschyni 2012: osnovni novatsii ta ikh vplyv na suspil'no-politychnyj rozvytok derzhavy [Hungary`s Constitutional Changes 2012 : basic innovations and their impact on the socio-political development of the country]. Viche: Teoretychnyj i hromads'kopolitychnyj zhurnal. - Viche, 4, 11-15 [in Ukrainian].

Popozych N. V., Postgraduate Student of the Scientific Research Institute of State Building and Local Government, National Academy of Legal Science of Ukraine, Ukraine, Kharkiv.

e-mail: n1popovych@gmail.com ; ORCID 0000-0003-0060-347X

\section{Constitutional laws in the Visegrad countries}

The article is devoted to investigation of the place of constitutional lawes in the system of constitutional legislation of association of four Central European countries: Poland, Hungary, the Slovak Republic and the Czech Republic; to study the nature and functional use of constitutional lazes, their specific characteristics and varieties, clarifying features, including special procedures for adoption and amendment of constitutional law and place in the legislation.

The current system of sources of law in Visegrad Group was formed under the influence of Roman, Austrian (Germanic), Socialist (Soviet) Law in the course of historical development, now it is identified as a system of civil law, which is changing and evolving under the influence of European international legal standards and values (laws of the European Union), formed primarily within the civil law. In the countries of the Visegrad Four constitutional laws are the integral part of the constitutional system. Thus, in countries of Visegrad Group functional use of constitutional lawes is different (amending; implementation of international agreements; regulation of certain matters provided by the constitution, etc.). It is also mentioned in the article that in Poland, the term «constitutional law» after adoption of the Constitution of 1997 is not applied officially in terms of legislation, though, at the same time some lawyers and politicians use the term in their publications and speeches, collectively interpreting the notion of constitutional law as the law that is first and utmost connected with the content of the Constitution, with amendments to the Constitution, and the adoption of the new Constitution.

It is noted that «constitutional lawes» can be understood not only as the laws that amend or supplement the Constitution but also as the lazes the Constitution refers to or necessity of which is directly provided by the current Constitution. These lawes specify certain provisions of the Constitution, are adopted by the legislature or a referendum in a specific order.

Keywords: Constitution; constitutional law; organic law; referendum; Visegrad Group.

Надійшла до редколегії 04.11.2016 р. 